\title{
Distribution and sources of air pollutants in the North China Plain based on on-road mobile measurements
}

\author{
Yi Zhu ${ }^{1}$, Jiping Zhang ${ }^{2}$, Junxia Wang ${ }^{1}$, Wenyuan Chen ${ }^{1}$, Yiqun Han ${ }^{1}$, Chunxiang Ye ${ }^{3}$, Yingruo Li $^{1}$, Jun Liu ${ }^{1}$, \\ Limin Zeng ${ }^{1}$, Yusheng $\mathrm{Wu}^{1}$, Xinfeng Wang ${ }^{4}$, Wenxing Wang ${ }^{4}$, Jianmin Chen ${ }^{4}$, and Tong $\mathrm{Zhu}^{1,5}$ \\ ${ }^{1}$ State Key Joint Laboratory of Environmental Simulation and Pollution Control, College of Environmental \\ Sciences and Engineering, Peking University, 100871 Beijing, China \\ ${ }^{2}$ Institute of Atmospheric Physics, Chinese Academy of Sciences, 100029 Beijing, China \\ ${ }^{3}$ School of Chemistry, University of Leeds, Leeds, LS2 9JT, UK \\ ${ }^{4}$ Environment Research Institute, School of Environmental Science and Engineering, \\ Shandong University, 250100 Ji'nan, China \\ ${ }^{5}$ The Beijing Innovation Center for Engineering Science and Advanced Technology, \\ Peking University, Beijing, China
}

Correspondence to: Tong Zhu (tzhu@pku.edu.cn)

Received: 14 May 2016 - Published in Atmos. Chem. Phys. Discuss.: 24 May 2016

Revised: 9 September 2016 - Accepted: 15 September 2016 - Published: 7 October 2016

\begin{abstract}
The North China Plain (NCP) has been experiencing severe air pollution problems with rapid economic growth and urbanisation. Many field and model studies have examined the distribution of air pollutants in the NCP, but convincing results have not been achieved, mainly due to a lack of direct measurements of pollutants over large areas. Here, we employed a mobile laboratory to observe the main air pollutants in a large part of the NCP from 11 June to 15 July 2013. High median concentrations of sulfur dioxide $\left(\mathrm{SO}_{2}\right)(12 \mathrm{ppb})$, nitrogen oxides $\left(\mathrm{NO}_{x}\right)\left(\mathrm{NO}+\mathrm{NO}_{2}\right.$; $452 \mathrm{ppb}$ ), carbon monoxide (CO) (956 ppb), black carbon (BC; $\left.5.5 \mu \mathrm{g} \mathrm{m}^{-3}\right)$ and ultrafine particles $\left(28350 \mathrm{~cm}^{-3}\right)$ were measured. Most of the high values, i.e. 95 percentile concentrations, were distributed near large cities, suggesting the influence of local emissions. In addition, we analysed the regional transport of $\mathrm{SO}_{2}$ and $\mathrm{CO}$, relatively long-lived pollutants, based on our mobile observations together with wind field and satellite data analyses. Our results suggested that, for border areas of the NCP, wind from outside this area would have a diluting effect on pollutants, while south winds would bring in pollutants that have accumulated during transport through other parts of the NCP. For the central NCP, the concentrations of pollutants were likely to remain at high levels, partly due to the influence of regional transport by
\end{abstract}

prevalent south-north winds over the NCP and partly by local emissions.

\section{Introduction}

The North China Plain (NCP) is a geographically flat region in the northern part of eastern China, which includes Beijing, Tianjin, most of Hebei, Henan and Shandong provinces and the northern parts of Anhui and Jiangsu provinces. This region is surrounded by the Yan Mountains to the north, the Taihang Mountains to the west and the Bohai Sea to the east. The NCP covers an area of $300000 \mathrm{~km}^{2}$, which corresponds to about $1 / 32$ of the total area of China, but is home to approximately $1 / 5$ of the Chinese population. The NCP is the political, economic and agricultural centre of China. Along with rapid economic growth and urbanisation, the NCP has been experiencing severe air pollution problems (Donkelaar et al., 2010). On a global scale, the NCP is a hotspot of nitrogen dioxide $\left(\mathrm{NO}_{2}\right)$, carbon monoxide $(\mathrm{CO})$, sulfate and particulate matter (PM) concentrations, according to both satellite observations and model simulations (Yu et al., 2010; Bechle et al., 2011; Streets et al., 2013; Bucsela et al., 2013). The concentrations of PM with an aerodynamic diameter $\leq 2.5 \mu \mathrm{m}\left(\mathrm{PM}_{2.5}\right)$ and $\mathrm{PM}_{10}$ in the NCP are much higher 
compared to other rapidly developing areas in China, such as the Yangtze River Delta (Hu et al., 2014; Wang et al., 2015). According to the air-quality report published by the Chinese Ministry of Environmental Protection, in 2013, 9 of the 10 most polluted cities in China are located in the NCP. Severe pollution events occur frequently in this area. Therefore, studies of air pollution problems in the NCP are essential to obtain general insights into the unique patterns of air pollution in this area and for the management of emissions control policies by the government.

Over the past decade, there have been a number of investigations of air pollution in the NCP, taking advantage of observation sites, aircraft measurement platforms, mobile laboratories, satellite data and air quality models. In the NCP, a network of observation sites has been built for air pollution research, mostly located in and around large cities, particularly Beijing (Xu et al., 2011, 2014; Wang et al., 2013; Meng et al., 2009; Shen et al., 2011; Lin et al., 2011; Li et al., 2015). Variability, sources and meteorological and chemical impacts of air pollutants have been discussed by analysing these observational results. The concentrations of long-lived pollutants have been shown to be significantly influenced by wind, particularly the south and north winds, indicating that regional transport plays an important role in urban air pollution. In addition, model studies have yielded similar results in various areas of the NCP (An et al., 2007; Zhang et al., 2008; Liu et al., 2013). Satellite data have indicated that regional transport has a significant impact on the haze period in the NCP (Wang et al., 2014). Thus, it is necessary to understand regional transport to address air pollution problems in the NCP, which will require data on the distribution of air pollutants in this region.

However, observational data from a single or limited number of measurement sites cannot present the whole picture of air pollution in the NCP. A number of mobile laboratory measurements (Johansson et al., 2008; Li et al., 2009; Wang et al., 2009, 2011) and aircraft measurements (Huang et al., 2010; Zhang et al., 2011, 2009, 2014) have been used to determine pollution distributions, mainly within the megacity of Beijing. There have been several reports of model and satellite studies on the air pollution distribution in the NCP, or even the whole of China (Wei et al., 2011; Zhao et al., 2013; Ying et al., 2014; Ding et al., 2015, 2009). However, there are disagreements between these results, e.g. regarding the distributions of $\mathrm{NO}_{2}$ in several hotspot areas produced from model (CMAQ) and satellite (SCIAMACHY) measurements (Shi et al., 2008). Uncertainties in model simulations, such as emissions inventories, and in satellite measurements, such as the influence of clouds, can only be evaluated by measuring the spatial distributions of pollutants over a large geographical area, which are still lacking.

In this study, we measured the concentrations of nitrogen oxides $\left(\mathrm{NO}_{x}\right), \mathrm{CO}$, sulfur dioxide $\left(\mathrm{SO}_{2}\right)$, ultrafine particles and black carbon (BC) with a mobile laboratory platform in the NCP. Satellite data and field wind measurements during the observation period were also used. Our specific objectives were to collect a dataset showing the spatial distribution of air pollutants in the NCP, and to characterise the regional transport within and outside the NCP. This study was performed as part of the Campaigns of Air Pollution Research in Megacity Beijing and North China Plain (CAREBeijingNCP 2013), and involved comprehensive stereoscopic observations, including observations of two super sites, several routine sites, mobile laboratories and model work. This paper focuses on the distribution and transport of pollutants in the NCP, mainly based on data collected from a mobile platform.

\section{Experimental methods}

\subsection{Mobile laboratory and study area}

A mobile laboratory was built by our research group, details of which were previously described (Wang et al., 2009). Briefly, this mobile laboratory was constructed in 2006 on an IVECO Turin V diesel vehicle (length $6.6 \mathrm{~m}$, width $2.4 \mathrm{~m}$, height $2.8 \mathrm{~m}$; payload $2.7 \mathrm{t}$ ). Instrumentation was powered by two sets of uninterruptible power systems (UPS), consisting of three series of $48 \mathrm{~V} / 110 \mathrm{Ah}$ lithium batteries, which could support all of the equipment operations without interruption for up to $5 \mathrm{~h}$. The inlet systems for our mobile laboratories were specifically configured to accommodate the type of measurement requirements and the instrument suite to be employed in specific field campaigns.

Instruments deployed on the mobile laboratory included those for studying $\mathrm{NO}_{x}, \mathrm{CO}, \mathrm{SO}_{2}, \mathrm{BC}$ and ultrafine particles. $\mathrm{NO}_{x}$ was measured using an $\mathrm{NO}_{x}$ analyser with a Mo converter (Ecotech model 9841A; Ecotech, Knoxfield, Melbourne, Australia). $\mathrm{CO}$ was measured using a $\mathrm{CO}$ analyser by light absorption (Ecotech model 9830A). $\mathrm{SO}_{2}$ was measured using an $\mathrm{SO}_{2}$ analyser with a fluorescence cell (Ecotech model 9850A). BC was measured using a multi-angle absorption photometer (MAAP; Thermo model 5012; Thermo Scientific, Waltham, MA). The precisions, uncertainties and time resolutions of these analysers are shown in Table 1. The online measurement data from these instruments were recorded with an industrial personal computer.

Each time before an experiment, we did a calibration to obtain calibration curves, e.g. on 16 June in 2013 (Fig. S2 in the Supplement), and after the experiment we did another calibration and recorded the span drifts. The span drifts were less than $10 \%$. For example, according to the calibration on 23 June in 2013, the span drifts of $\mathrm{NO}, \mathrm{SO}_{2}$ and $\mathrm{CO}$ were 29 (365) ppb, 9 (160) ppb and 0.1 (7.4) ppm. In a previous study we also did an intercomparison with the monitoring station in the campus of Peking University (Wang et al., 2009).

Ultrafine particles were measured using a fast mobility particle sizer (FMPS, TSI 3090; TSI, Shoreview, MN), which covers particle sizes from 5.6 to $560 \mathrm{~nm}$ in 32 channels with a time resolution of $0.1 \mathrm{~s}$. The data were recorded on a desig- 
Table 1. Precisions and uncertainties of air pollutants analysers used in our experiments.

\begin{tabular}{lrrrr}
\hline & $\mathrm{NO}_{x}$ & $\mathrm{CO}$ & $\mathrm{SO}_{2}$ & $\mathrm{BC}$ \\
\hline Precision & $1 \%$ & $1 \%$ & $0.5 \%$ & $0.1 \mu \mathrm{g} \mathrm{m}^{-3}$ \\
Uncertainty & $<10 \%$ & $<100 \mathrm{ppb}$ & $<10 \%$ & $<1 \%$ \\
Time resolution & $30 \mathrm{~s}$ & $40 \mathrm{~s}$ & $120 \mathrm{~s}$ & $6 \mathrm{~s}$ \\
\hline
\end{tabular}

nated computer. Other auxiliary data including temperature, relative humidity, barometric pressure and GPS coordinates were also measured. The driving speed was kept stable at around $100 \pm 5 \mathrm{~km} \mathrm{~h}^{-1}$ to cover as much distance as possible with the $5 \mathrm{~h}$ of power supplied by the lithium batteries.

To establish the spatial distribution and characterise the regional transport of air pollutants in the NCP, the routes for the mobile measurements were specially designed to cover important emissions hotspots (Fig. 1) and to map large areas of the NCP. The routes included the municipalities of Beijing and Tianjin, most of Hebei province, and part of Shandong province, which is about $300 \mathrm{~km}$ wide from the west to the east and $400 \mathrm{~km}$ long from the north to the south, covering most of the NCP. To avoid traffic jams and rough roads, only motorways were chosen for all routes. Limited by the duration of battery power and the variability of boundary layer height, we could not cover all routes in one trip. Instead, we divided the routes into five parts. Route 1 was along the Taihang Mountains from Beijing to Shijiazhuang, located in the western part of the NCP. Routes 2 and 3 were from Shijiazhuang to Dezhou and Cangzhou to Baoding, respectively, which were generally located in the central NCP. Routes 4 and 5 were from Tianjin to Beijing and around the south of Beijing, located in the northern NCP. In addition, we ran each route in 1 day. Two days were also needed for calibration and maintenance of instruments. Therefore, it took 1 whole week to conduct a single experiment. In total, six experiments, including one pre-test study, were designed from 1 June to 15 July 2013 . The pre-test study was conducted between 1 and 7 June, and five formal repeated experiments were conducted between 11 June and 15 July (Experiment 1 (E1), 1115 June; E2, 17, 18 and 20 June; E3, 24-25 June; E4, 27 July; E5, 11-15 July). All trips were started at about 09:5510:50 LT (local time) and ended at about 13:05-15:05 LT to ensure that the boundary layer was relatively stable during the observation period in 1 day.

The major reasons for data lacking were the computer crashing and rain. Rain caused the missing data on routes 3, 4 and 5 in experiment 3 , and on route 5 in experiment 5 . The computer crashing caused the missing data on routes 4 and 5 in experiment 2 (Table S1). The computer crashing also caused missing data during every trip (Table S2).

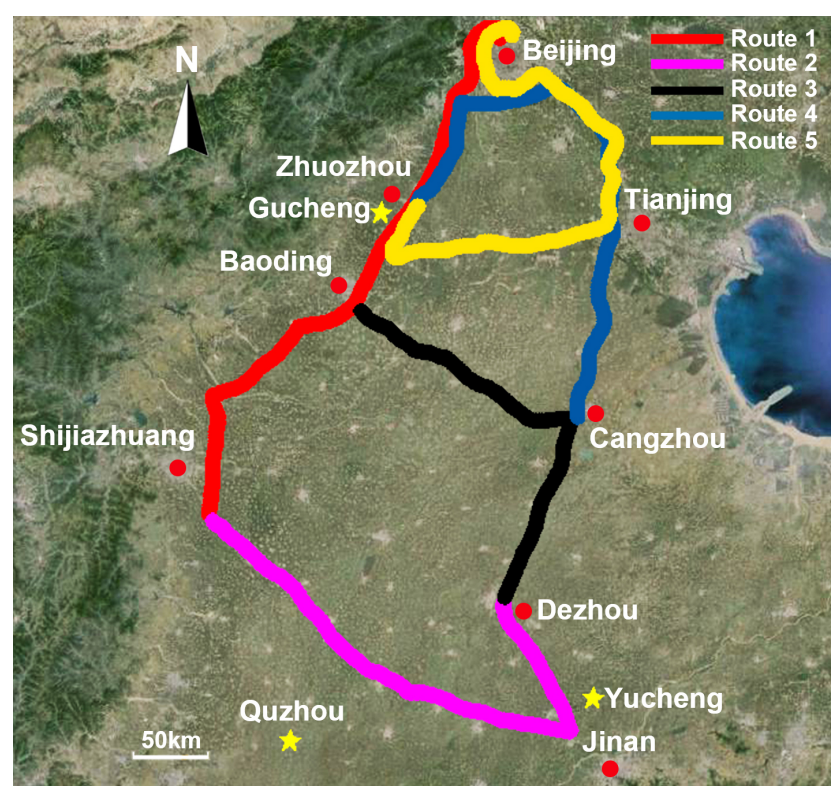

Figure 1. The study area in NCP. The red track shows route 1, from Beijing to Shijiazhuang. The purple track shows route 2, from Shijiazhuang to Dezhou. The black track shows route 3, from Dezhou to Baoding. The blue track shows route 4, from Cangzhou to Zhuozhou. The yellow track shows route 5, from Zhuozhou to Beijing. The red dots on the map present the major cities near the routes. The yellow stars present the monitoring sites.

\subsection{The trajectories model}

A Lagrangian particle dispersion model, FLEXPART-WRF version 3.1 (Brioude et al., 2013; Stohl, 1998; Stohl et al., 2005; Fast and Easter, 2006), was used to determine the origin and transport pathways of the air mass arriving at the vehicle-based mobile measurement laboratory. The wind field used to drive FLEXPART was the time-averaged wind provided by the WRF (Weather Research and Forecasting) model, with temporal intervals of $10 \mathrm{~min}$ and horizontally spatial resolution of $2 \mathrm{~km}$. (The details of the mesoscale meteorological model are described in Sect. S2.1 in the Supplement.) FLEXPART simulates the transport and dispersion of tracers by calculating the backward trajectories of multitudinous particles, which are termed plume back trajectories. In this model, turbulence in the planetary boundary layer is parameterised by solving the Langevin equation, and convection is parameterised using the Živković-Rothman scheme (Stohl et al., 2005). To improve the accuracy of the trajectory calculation, we used high-resolution WRF simulation domain 4 outputs as the input meteorological conditions for the FLEXPART model. The turbulence, convection and boundary layer height were computed along the trajectories of tracer particles using the WRF output data. Backward integration was performed every $5 \mathrm{~min}$ during the mobile observation period in June 2013. For each integration, 2000 stochastic particles were released initially from within a 
box $1 \times 1 \mathrm{~km}^{2}$ in horizontal extent and $1-50 \mathrm{~m}$ vertical height above ground centred on the mobile measurement laboratory. A total of 2000 inert tracer particles were released about every $5 \mathrm{~min}$ along the route of the vehicle. For each release, the backward trajectories were simulated for at least $12 \mathrm{~h}$, and the particle locations were output every $10 \mathrm{~min}$ for analysis. The $12 \mathrm{~h}$ length of the backward trajectories was chosen as a trade-off to adequately sample the history of the air masses over the region of interest, while decreasing the trajectory error (Stohl, 1998; Zhang et al., 2012).

The footprints of backward trajectories were calculated to present plume trajectories. Footprints in this context refer to the total residence times of released particles, which were calculated following Ashbaugh et al. (1985) and de Foy et al. (2009) by counting the accumulated number of particles during the integration within each cell of a $2 \times 2 \mathrm{~km}^{2}$ grid. Various transport and diffusion patterns can well be described by these footprint analyses (Zhang et al., 2012).

\subsection{Stationary measurement sites and the fire data}

Concentrations of air pollutants, including $\mathrm{NO}_{x}, \mathrm{SO}_{2}, \mathrm{CO}$ and $\mathrm{BC}$, were measured simultaneously at three stationary measurement sites during CAREBeijing-NCP 2013. These were rural sites located at Gucheng, Hebei province $\left(\mathrm{GC}, 39.13^{\circ} \mathrm{N}, 115.67^{\circ} \mathrm{E}\right)$; Quzhou, Hebei province (QZ, $36.78^{\circ} \mathrm{N}, 114.92^{\circ} \mathrm{E}$ ); and Yucheng, Shandong province (YC, $36.67^{\circ} \mathrm{N}, 116.37^{\circ} \mathrm{E}$ ) (Fig. 1). The GC stationary site was near route 1 , and QZ and YC stationary sites were near route 2 . The straight-line distances from these stationary sites to the nearest measuring roads were $3 \mathrm{~km}$ from GC station to route $1,54 \mathrm{~km}$ from QZ station and $5 \mathrm{~km}$ from YC station to route 2 . These stationary data were hourly averages. The concentrations plotted in Fig. 2 were hourly average results when our mobile laboratory passed by these stations. Furthermore, the footprint maps (Figs. 7 and S6) show the wind directions and wind speeds at these sites.

The main pollutants at these sites were measured using commercial instruments. At the QZ site, gas analysers were used to measure $\mathrm{NO}_{x}$ (Ecotech model 9841A), CO (Ecotech model 9830A) and $\mathrm{SO}_{2}$ (Ecotech model 9850A). At GC and YC stations, gas analysers were used to measure $\mathrm{NO}_{x}$ (Thermo model 42C), $\mathrm{CO}$ (Thermo model 48i) and $\mathrm{SO}_{2}$ (Thermo model $48 \mathrm{i}$ ), and $\mathrm{BC}$ was measured by MAAP (Thermo model 5012).

Fire data were obtained from the Moderate Resolution Imaging Spectroradiometer (MODIS) installed in Terra and Aura. The territory passing times were 10:30 and 13:30 LT for Terra and Aura, respectively. Fire images were obtained from EOSDIS Worldview (NASA, https://earthdata. nasa.gov/labs/worldview).

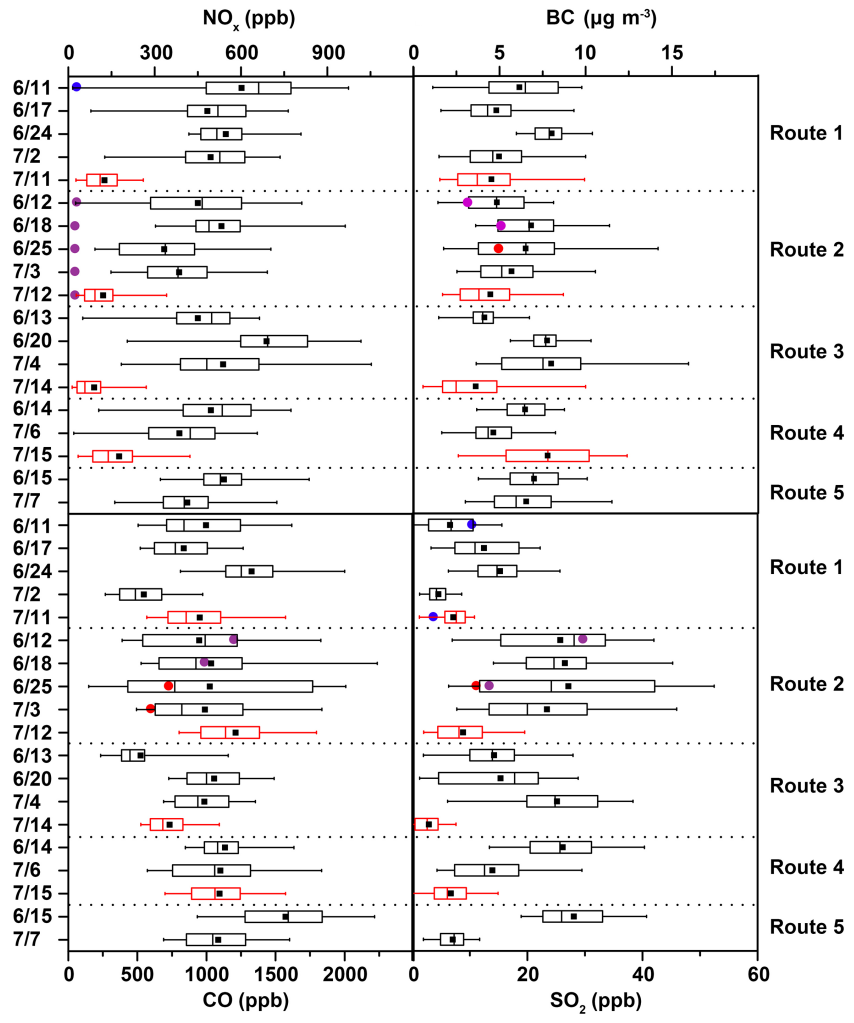

Figure 2. The concentrations of $\mathrm{SO}_{2}, \mathrm{CO}, \mathrm{BC}$ and $\mathrm{NO}_{x}$ in each trip in different routes. The red boxes were the results in the last experiment. Values marked were the 5th and 95th percentile (-), standard deviation (lower and upper box lines), median (middle box line) and mean ( $\mathbf{\square})$. The blue dots were results from the GC station. The purple dots were results of QZ station. The red dots were results from the YC station.

\section{Result and discussion}

\subsection{Distribution of air pollutants}

$\mathrm{BC}, \mathrm{NO}_{x}, \mathrm{CO}$ and $\mathrm{SO}_{2}$ were measured on five routes during the experiment to determine the concentrations of air pollutants on the routes and their spatial distributions in the NCP. Figure 2 shows the results of our mobile measurements obtained in 19 trips on the five routes from 11 June to 15 July. The mean and median concentrations of $\mathrm{BC}, \mathrm{NO}_{x}$, $\mathrm{CO}$ and $\mathrm{SO}_{2}$ were 5.8 and $5.5 \mu \mathrm{g} \mathrm{m}^{-3}, 422$ and $452 \mathrm{ppb}$, 1006 and $956 \mathrm{ppb}$ and 15 and $12 \mathrm{ppb}$, respectively, in the whole study. These high values were consistent with previous measurements of most pollutants at stationary measurement sites in the NCP except for $\mathrm{NO}_{x}$. For example, the measured concentrations of $\mathrm{NO}_{x}, \mathrm{SO}_{2}$ and $\mathrm{CO}$ were $62.7 \pm 4.0$, $31.9 \pm 2.0$ and $1990 \pm 130 \mathrm{ppb}$ in an urban site in the courtyard of China Meteorological Administration in the Beijing area from 17 November 2007 to 15 March 2008 (Lin et al., 2011). These values were $13-50 \mathrm{ppb}, 5.7-30.3 \mathrm{ppb}$ and $1100-1800 \mathrm{ppb}$ at an urban site in Wuqing (between Beijing 

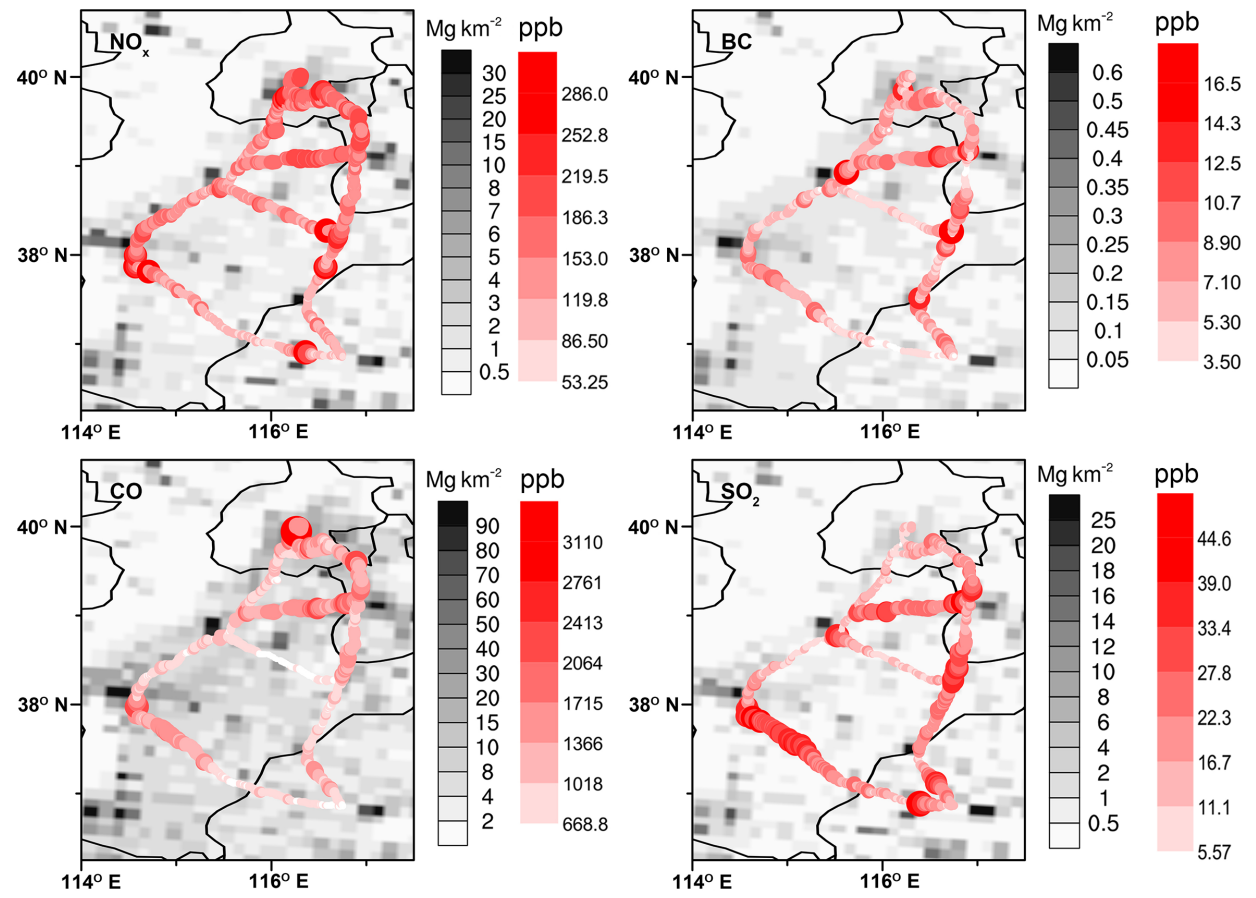

Figure 3. The spatial distributions of the measured concentrations in our study and the emission maps of $\mathrm{SO}_{2}, \mathrm{NO}_{x}, \mathrm{CO}$ and $\mathrm{BC}$. The coloured tracks were average concentrations measured in this mobile observation. The black and white maps were emission maps from the year 2010 derived from the MEIC model (Zhao et al., 2013).

and Tianjin) from 9 July 2009 to 21 January 2010 (Xu et al., 2011); and 28.4, 17.2 and $1520 \mathrm{ppb}$ at the GC site from July 2006 to September 2007 (Lin et al., 2009). In addition, the concentration of $\mathrm{NO}_{2}$ measured at the $\mathrm{YC}$ site from 18 to 30 June was about $20 \mathrm{ppb}$ (Wen et al., 2015). This comparison with stationary site measurements suggested that our mobile measurements reflected the heavily polluted conditions in the NCP, which ensured its feasibility in profiling the distributions of these air pollutants.

The levels of $\mathrm{CO}, \mathrm{NO}_{x}$ and $\mathrm{BC}$ here were also comparable to those in previous mobile laboratory measurements in European and American cities. Bukowiecki et al. (2002) measured CO in Zürich, Switzerland, and the average concentration was about $600 \mathrm{ppb}$. Hagemann et al. (2014) measured $\mathrm{NO}_{x}$ in Karlsruhe in Germany, and the average concentration was about $20 \mathrm{ppb}$. In the USA, $\mathrm{NO}_{x}$ was around $50 \mathrm{ppb}$ in Somerville (Padró-Martínez et al., 2012), 200 ppb during rush hour in Boston (Kolb et al., 2004) and ranged from 230 to $470 \mathrm{ppb}$ in Los Angeles (Westerdahl et al., 2005). PadróMartínez et al. (2012) also measured BC in Somerville, and reported average concentrations of about $1 \mu \mathrm{g} \mathrm{m}^{-3}$. As these measurements were obtained in areas of heavy traffic in large cities, and our results were measured over a large region, we concluded that the air pollution problems in the NCP are among the worst in the world. In contrast to these pollutants, a low concentration of $\mathrm{SO}_{2}$ was consistently measured throughout the whole study.
As shown in Fig. 3, the concentrations of $\mathrm{BC}, \mathrm{NO}_{x}, \mathrm{CO}$ and $\mathrm{SO}_{2}$ were highly variable on the different routes in the NCP. The concentration ranges of these four species were 5-14 $\mu \mathrm{g} \mathrm{m}^{-3}$ for $\mathrm{BC}, 447-891 \mathrm{ppb}$ for $\mathrm{NO}_{x}, 22.6-40.4 \mathrm{ppb}$ for $\mathrm{SO}_{2}$ and $1105-1652 \mathrm{ppb}$ for $\mathrm{CO}$. These extremely high values, i.e. 95 percentile concentrations, were consistently found in various plumes near these emissions hotspots in the $\mathrm{NCP}$, which suggested a major influence on concentrations of measured species in these hotspot areas by local emissions. The hotspots observed here were mainly around the junction areas of our design routes, and they included, but were not limited to, areas of Beijing, Tianjin, Baoding, Cangzhou, Dezhou, Shijiazhuang and Zhuozhou. Previous model simulations and satellite measurements in the $\mathrm{NCP}$ also confirmed the high concentrations of $\mathrm{NO}_{2}$ around these large cities (Shi et al., 2008). It is worth noting that these observed concentration hotspots moved around the emissions hotspots, probably as a result of the varied transport processes in different trips. For example, a pollution plume was detected $100 \mathrm{~km}$ to the south of Cangzhou on 20 June, but $130 \mathrm{~km}$ to the north of Cangzhou on 6 July. In addition, plumes were not always detected in different experiments around these cities, with the exception of Shijiazhuang.

During the five experiments, no clear temporal distributions of air pollutant concentrations in the NCP were seen, except for the significantly low levels of $\mathrm{NO}_{x}$ and $\mathrm{SO}_{2}$ observed in the last experiments. However, no connections be- 
Table 2. The concentrations of $\mathrm{NO}_{x}, \mathrm{CO}, \mathrm{SO}_{2}$ and $\mathrm{BC}$ measured in car parks and motorways, and the concentration differences between off-road and on-road measurement.

\begin{tabular}{|c|c|c|c|c|c|c|c|c|c|}
\hline \multirow[t]{3}{*}{ Date } & \multirow{3}{*}{$\begin{array}{l}\text { Car } \\
\text { parks }\end{array}$} & \multicolumn{8}{|c|}{ Concentrations } \\
\hline & & \multicolumn{4}{|c|}{$\mathrm{NO}_{x}(\mathrm{ppb})$} & \multicolumn{4}{|c|}{$\mathrm{CO}(\mathrm{ppb})$} \\
\hline & & $\begin{array}{r}\text { Off-road } \\
(\mathrm{C} 1)\end{array}$ & $\begin{array}{r}\text { On-road } \\
(\mathrm{C} 2)\end{array}$ & $\mathrm{C} 2-\mathrm{C} 1$ & $\frac{\mathrm{C} 2-\mathrm{C} 1}{\mathrm{C} 1}$ & $\begin{array}{r}\text { Off-road } \\
(\mathrm{C} 1)\end{array}$ & $\begin{array}{r}\text { On-road } \\
(\mathrm{C} 2)\end{array}$ & $\mathrm{C} 2-\mathrm{C} 1$ & $\frac{\mathrm{C} 2-\mathrm{C} 1}{\mathrm{C} 1}$ \\
\hline 11 Jun & XZT & 234 & 643 & 409 & $175 \%$ & 694 & 677 & -17 & $-2 \%$ \\
\hline 12 Jun & $\mathrm{XZT}$ & 411 & 699 & 288 & $70 \%$ & 1050 & 1098 & 48 & $5 \%$ \\
\hline 12 Jun & $\mathrm{DZ}$ & 20 & 106 & 86 & $430 \%$ & 396 & 506 & 110 & $28 \%$ \\
\hline 13 Jun & $\mathrm{DZ}$ & 19 & 334 & 315 & $1658 \%$ & 431 & 576 & 145 & $34 \%$ \\
\hline 17 Jun & XZT & 30 & 297 & 267 & $890 \%$ & 1000 & 1086 & 86 & $9 \%$ \\
\hline 18 Jun & $\mathrm{XZT}$ & 109 & 468 & 359 & $329 \%$ & 1212 & 955 & -257 & $-21 \%$ \\
\hline 18 Jun & $\mathrm{DZ}$ & 372 & 677 & 305 & $82 \%$ & 588 & 711 & 123 & $21 \%$ \\
\hline $3 \mathrm{Jul}$ & $\mathrm{XZT}$ & 49 & 498 & 449 & $916 \%$ & 826 & 861 & 35 & $4 \%$ \\
\hline \multirow[t]{3}{*}{$12 \mathrm{Jul}$} & $\mathrm{XZT}$ & 44 & 63 & 19 & $43 \%$ & 1708 & 1230 & -478 & $-28 \%$ \\
\hline & & \multicolumn{4}{|c|}{$\mathrm{SO}_{2}(\mathrm{ppb})$} & \multicolumn{4}{|c|}{$\mathrm{BC}\left(\mu \mathrm{g} \mathrm{m}^{-3}\right)$} \\
\hline & & $\begin{array}{r}\text { Off-road } \\
(\mathrm{C} 1)\end{array}$ & $\begin{array}{r}\text { On-road } \\
(\mathrm{C} 2)\end{array}$ & $\mathrm{C} 2-\mathrm{C} 1$ & $\frac{\mathrm{C} 2-\mathrm{C} 1}{\mathrm{C} 1}$ & $\begin{array}{r}\text { Off-road } \\
(\mathrm{C} 1)\end{array}$ & $\begin{array}{r}\text { On-road } \\
(\mathrm{C} 2)\end{array}$ & $\mathrm{C} 2-\mathrm{C} 1$ & $\frac{\mathrm{C} 2-\mathrm{C} 1}{\mathrm{C} 1}$ \\
\hline 11 Jun & XZT & 11.3 & 12.7 & 1.4 & $12 \%$ & 2.3 & 5.6 & 3.3 & $143 \%$ \\
\hline 12 Jun & $\mathrm{XZT}$ & 24.4 & 30.9 & 6.5 & $27 \%$ & 2.9 & 6.6 & 3.7 & $128 \%$ \\
\hline 12 Jun & $\mathrm{DZ}$ & 8.9 & 10.0 & 1.1 & $12 \%$ & 1.5 & 4.1 & 2.6 & $173 \%$ \\
\hline 13 Jun & $\mathrm{DZ}$ & 14.6 & 12 & -2.6 & $-18 \%$ & 2.3 & 3.6 & 1.3 & $57 \%$ \\
\hline 17 Jun & XZT & 11 & 17 & 6 & $55 \%$ & 3.4 & 5.5 & 2.1 & $62 \%$ \\
\hline 18 Jun & XZT & 15 & 28 & 13 & $87 \%$ & 6.6 & 5.9 & -0.7 & $-11 \%$ \\
\hline 18 Jun & DZ & 17 & 21 & 4 & $24 \%$ & 7.4 & 10.3 & 2.9 & $39 \%$ \\
\hline $3 \mathrm{Jul}$ & XZT & 17 & 21.9 & 4.9 & $29 \%$ & 1.8 & 6.5 & 4.7 & $261 \%$ \\
\hline $12 \mathrm{Jul}$ & XZT & 1.2 & 3.3 & 2.1 & $175 \%$ & 5.3 & 6.2 & 0.9 & $17 \%$ \\
\hline
\end{tabular}

tween the decline in $\mathrm{NO}_{x}$ and $\mathrm{SO}_{2}$ concentrations and emissions or transport could be made. In fact, precipitation caused the low concentrations of $\mathrm{NO}_{x}$ and $\mathrm{SO}_{2}$ in the last experiment in NCP. In addition, all measuring areas were affected by heavy rain, so the concentrations of $\mathrm{NO}_{x}$ and $\mathrm{SO}_{2}$ on all routes were low.

In summary, our mobile laboratory measurements indicated spatial distributions of the pollutants $\mathrm{SO}_{2}, \mathrm{CO}$ and $\mathrm{BC}$ and the number density of fine particles. The concentrations of air pollutants in the NCP were among the highest in the world, and extremely high concentrations were also observed around several cities.

\subsection{The influence of traffic emission}

The levels and distributions of air pollutants in the NCP are mainly attributable to three sources, i.e. regional transport, local emissions and traffic emissions. On-road measurements, however, could be greatly affected by traffic emissions (Wang et al., 2009). The influence of traffic emissions on our mobile laboratory measurements is discussed below.

\subsubsection{Comparing the on- and off-road measurements of air pollutants to estimate the enhancement of air pollution on motorways above the regional background}

Each on-road measurement trip started from a car park in a motorway service station and ended at the car park of another service station. The car parks are about $150 \mathrm{~m}$ away from the motorway, such as those in service stations Dezhou (DZ) and Xizhaotong (XZT) (Fig. S3). Using the difference of the concentrations of air pollutants measured in car parks and on motorways, we can estimate the level of the enhancement of the concentrations of air pollutants on motorways for backgrounds greater than on a regional level.

Table 2 shows the 5 min averaged concentrations of $\mathrm{NO}_{x}$, $\mathrm{CO}, \mathrm{SO}_{2}$ and $\mathrm{BC}$ measured in car parks and on motorways, and the difference between the on- and off-road concentrations. The concentrations in car parks were measured for $5 \mathrm{~min}$ before driving or after parking with engine turned off, and the concentrations on motorways were measured for $5 \mathrm{~min}$ after entering motorways or $5 \mathrm{~min}$ before entering the service stations. 
The concentrations of $\mathrm{NO}_{x}$ measured on motorways show drastic enhancement than those measured off-road, from 19 to $449 \mathrm{ppb}$, or 43 to $1658 \%(510 \pm 61 \%$, mean \pm standard deviation), while other pollutants have much lower enhancement or even reduction in concentrations. The difference between the on-road and off-road concentrations of $\mathrm{CO}$ ranged from -478 to $145 \mathrm{ppb}$, or -28 to $34 \%$ (7 $\pm 22 \%)$; for $\mathrm{SO}_{2}$, it is -26 to $13 \mathrm{ppb}$ or -18 to $175 \%(52 \pm 59 \%)$; for $\mathrm{BC}$, it is -0.7 to $4.7 \mu_{\mathrm{g} \mathrm{m}^{-3}}$ or -11 to $261 \%(85 \pm 90 \%)$.

The $175 \%$ enhancement of $\mathrm{SO}_{2}$ on 12 July could be due to the much lower $\mathrm{SO}_{2}$ concentration, 1.2 to $3.3 \mathrm{ppb}$, than those measured on other days. The rain on 12 July is likely the major reason for the much lower concentrations of $\mathrm{SO}_{2}(3 \mathrm{ppb})$ and $\mathrm{NO}_{x}(63 \mathrm{ppb})$, while $\mathrm{CO}$ and $\mathrm{BC}$, which are much less water-soluble, show no significant difference to those measured on other days. If we ignore the results of $\mathrm{SO}_{2}$ and $\mathrm{NO}_{x}$ on 12 July, then the differences between the on- and off-road concentrations were 82 to $1658 \%(510 \pm 61 \%)$ for $\mathrm{NO}_{x}$ and were -18 to $87 \%(31 \pm 31 \%)$ for $\mathrm{SO}_{2}$.

Apparently, vehicular emission is the major source that led to the 82 to $1658 \%$ enhancement of $\mathrm{NO}_{x}$ concentrations on motorways. The enhancement of $\mathrm{CO}$ and $\mathrm{SO}_{2}$ concentrations on motorways was mostly less than $30 \%$, suggesting vehicular emission is not the main source of $\mathrm{CO}$ and $\mathrm{SO}_{2}$ on motorways; the regional background is the dominant factor that determines their concentrations.

\subsubsection{Time series of the concentrations of air pollutants measured on motorways}

Figure 4 shows the concentrations of $\mathrm{NO}_{x}, \mathrm{CO}, \mathrm{SO}_{2}$ and $\mathrm{BC}$ measured on motorways on a typical day, 13 June 2013. Apparently, the concentration of $\mathrm{BC}$ follows the trend of $\mathrm{NO}_{x}$ concentration and those of $\mathrm{CO}$ and $\mathrm{SO}_{2}$ did not. This suggests that the high enhancement of $\mathrm{NO}_{x}$ and $\mathrm{BC}$ concentration on motorways was due to the vehicular emission, while the concentrations of $\mathrm{CO}, \mathrm{SO}_{2}$ were not.

\subsubsection{Using the ratios of weighted vehicular emission factors to estimate the concentration enhancement of $\mathrm{NO}_{x}, \mathrm{CO}, \mathrm{SO}_{2}$ and $\mathrm{BC}$ measured on motorways}

Based on the reported vehicular emission factors (Shen et al., 2015; Cai and Xie, 2007, 2010; Lei et al., 2011) and the vehicle composition (Chinese Automotive Technology \& Research Centre, 2015) in Hebei province, where we conducted the most of the mobile measurements, we estimated the weighted vehicular emission factors on the motorways (Table 3). The factors for $\mathrm{NO}_{x}, \mathrm{CO}, \mathrm{SO}_{2}$ and $\mathrm{BC}$ during our measurements were $2.9,4.8,0.04$ and $0.01 \mathrm{~g} \mathrm{~km}^{-1}$, respectively. If we assumed $400 \mathrm{ppb}$ as the $\mathrm{NO}_{x}$ concentration enhancement on-road caused by vehicular emission, using the ratios of the weighted vehicular emission factors, the estimated enhancements of $\mathrm{CO}, \mathrm{SO}_{2}$ and $\mathrm{BC}$ concentrations on-

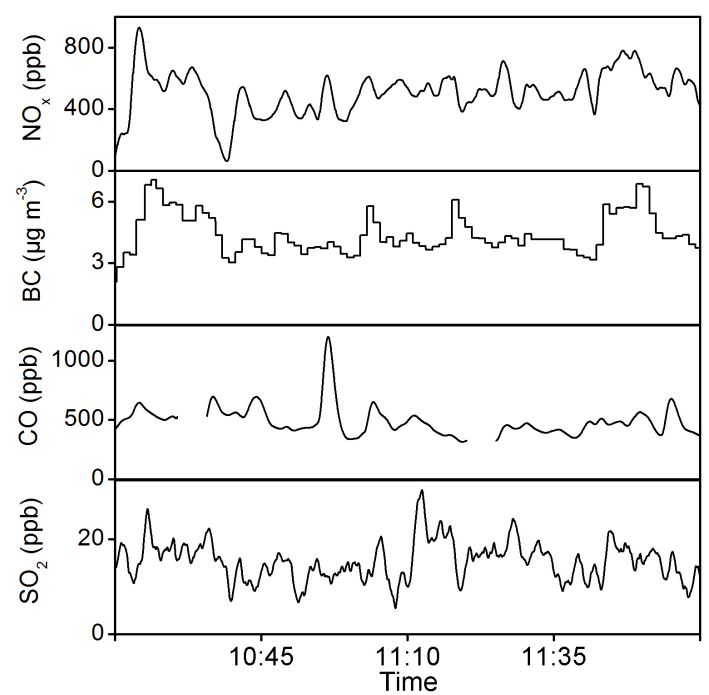

Figure 4. The time series of the concentrations of $\mathrm{NO}_{x}, \mathrm{CO}, \mathrm{SO}_{2}$ and $\mathrm{BC}$ measured on 13 June.

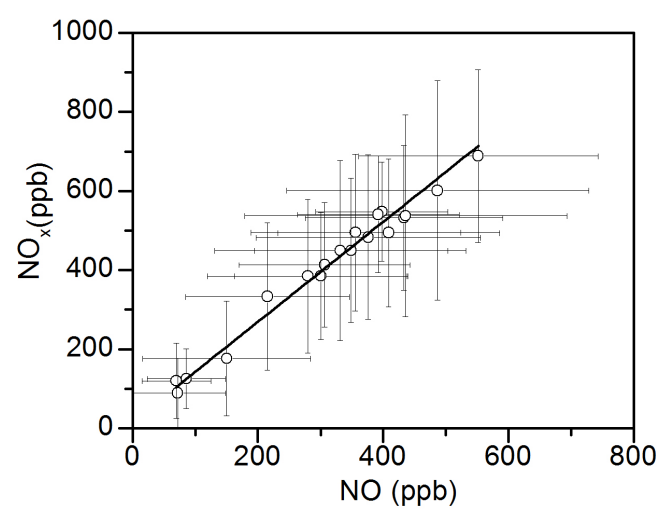

Figure 5. The regression curve of the means of concentrations of $\mathrm{NO}_{x}$ and $\mathrm{NO}$ and the error bars in all 19 trips.

road emitted by vehicles were $240 \mathrm{ppb}, 3 \mathrm{ppb}$ and $1 \mu \mathrm{g} \mathrm{m}^{-3}$. These are at similar levels to the enhancement shown in Table 1, suggesting vehicular emission is the main source of the enhancement of the on-road concentrations of $\mathrm{NO}_{x}, \mathrm{CO}, \mathrm{SO}_{2}$ and $\mathrm{BC}$. However, the enhancement of $\mathrm{CO}$ and $\mathrm{SO}_{2}$ concentrations on motorways was mostly less than $30 \%$; this provides further evidence that $\mathrm{CO}$ and $\mathrm{SO}_{2}$ concentrations on motorways were dominated by the regional background, and vehicular emission was not the main source.

\subsubsection{Correlations between $\mathrm{NO}_{x}, \mathrm{CO}, \mathrm{SO}_{2}$ and $\mathrm{BC}$ with NO}

A strong correlation $\left(r^{2}=0.99\right)$ was found between on-road $\mathrm{NO}_{x}$ and $\mathrm{NO}$ (Fig. 5), with an average $\mathrm{NO} / \mathrm{NO}_{2}$ ratio of 4 , which was much higher than the value of $0.05-0.2$ in the aged plumes (Finlayson-Pitts and Pitts, 2010). The results indicated that $\mathrm{NO}_{x}$ observed by our mobile laboratory was 
Table 3. Estimated weighted vehicular emission factors of $\mathrm{CO}, \mathrm{NO}_{x}, \mathrm{SO}_{2}$ and $\mathrm{BC}$ during mobile measurements in Hebei province, China.

\begin{tabular}{lrrrrr}
\hline Vehicle type & Composition & \multicolumn{4}{c}{ Emission factors } \\
\cline { 3 - 6 } & & $\mathrm{CO}^{\mathrm{a}} \mathrm{g} \mathrm{km}^{-1}$ & $\mathrm{NO}_{x}^{\mathrm{a}} \mathrm{g} \mathrm{km}^{-1}$ & $\mathrm{SO}_{2}^{\mathrm{b}} \mathrm{g} \mathrm{km}^{-1}$ & $\mathrm{BC}^{\mathrm{c}} \mathrm{g} \mathrm{km}^{-1}$ \\
\hline Diesel bus & $20 \%$ & 1.2 & 11 & - & - \\
Medium-duty diesel vehicles & $20 \%$ & 1.5 & 6.4 & - & - \\
Light-duty gasoline vehicles & $50 \%$ & 4.4 & 1.3 & - & - \\
Heavy-duty vehicles & $10 \%$ & 1.6 & 6.6 & 0.4 & 0.11 \\
\hline Weighted emission factor & & 2.9 & 4.8 & 0.04 & 0.01 \\
\hline
\end{tabular}

${ }^{a}$ Shen et al. (2015). ${ }^{\mathrm{b}}$ Cai and Xie (2007). ${ }^{\mathrm{c}}$ Lei et al. (2011).

mostly influenced by fresh vehicle emissions. Overall, the on-road $\mathrm{NO}_{x}$ observations here were not representative of the $\mathrm{NO}_{x}$ levels in the NCP. The concentrations of $\mathrm{BC}, \mathrm{CO}$ and $\mathrm{SO}_{2}$ were not correlated with those of $\mathrm{NO}$.

\subsubsection{Possible traffic jams and high concentrations of air pollutants}

Each on-road measurement trip started from a car park in a motorway service station and ended at the car park of another service station. The driven speed of the mobile platform was never lower than $80 \mathrm{~km} \mathrm{~h}^{-1}$ on motorways; this is one piece of evidence that we encountered no traffic jams, and the number of vehicles around our mobile platform seldom increased.

During our measurements, as shown in Fig. 3, we always measured high concentrations of air pollutants near large cities. As the time series of the concentrations of $\mathrm{NO}_{x}, \mathrm{CO}$, $\mathrm{SO}_{2}$ and $\mathrm{BC}$ measured on 13 June (Fig. 6) show, when approaching Baoding, $\mathrm{CO}$ concentration gradually increased from $500 \mathrm{ppb}$ at $50 \mathrm{~km}$ away from Baoding to $1200 \mathrm{ppb}$ at $23 \mathrm{~km}$ away from Baoding. The same is shown by $\mathrm{SO}_{2}$ (from 10 to $40 \mathrm{ppb}$ ) and $\mathrm{BC}$ (from 4 to $8 \mu \mathrm{g} \mathrm{m}^{-3}$ ), while $\mathrm{NO}_{x}$ does not show the same trend. When at $15 \mathrm{~km}$ away from Baoding, we see another increase of all the pollutants, and the same decrease trend after at $10 \mathrm{~km}$ from Baoding. The same continuously increasing trends of $\mathrm{SO}_{2}$ and $\mathrm{CO}$, which started at $50 \mathrm{~km}$ and continued to $15 \mathrm{~km}$ away from Baoding, indicated the regional transport of $\mathrm{SO}_{2}$ and $\mathrm{CO}$. Starting $15 \mathrm{~km}$ away from Baoding, all the four pollutants had a peak with about $10 \mathrm{~km}$ width, which indicated the urban emissions.

In summary, both the comparison of on- and off-road measured concentrations and the vehicular emission factors provided evidence as follows.

1. Vehicular emission is the main source of the enhancement of the on-road concentrations of $\mathrm{NO}_{x}, \mathrm{CO}, \mathrm{SO}_{2}$ and $\mathrm{BC}$.

2. The high enhancement of $\mathrm{NO}_{x}$ concentration on motorways was demonstrated, suggesting $\mathrm{NO}_{x}$ on motorways was mainly from vehicular emission.

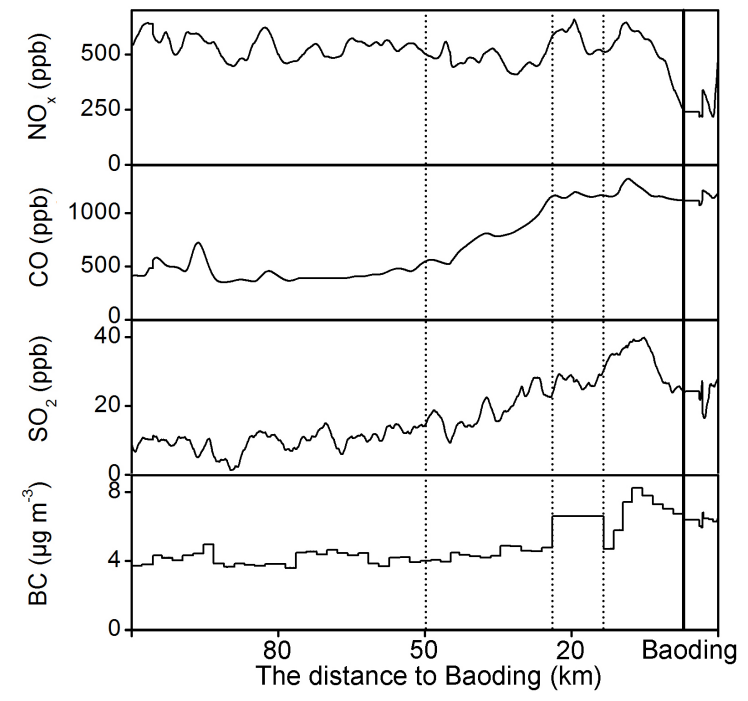

Figure 6. The time series of the concentrations of $\mathrm{NO}_{x}, \mathrm{CO}, \mathrm{SO}_{2}$ and $\mathrm{BC}$ measured on 13 June (the three dashed lines mark 50, 23 and $15 \mathrm{~km}$ to Baoding, and the solid line marks the location of Baoding).

3. $\mathrm{CO}$ and $\mathrm{SO}_{2}$ concentration have up to 20 and $31 \%$ average enhancement on motorways, suggesting that $\mathrm{CO}$ and $\mathrm{SO}_{2}$ on motorways were mainly from regional background.

4. The difference in the enhancement is the difference of level of background contribution. $\mathrm{NO}_{x}$ has a shorter lifetime, while the lifetimes of $\mathrm{CO}$ and $\mathrm{SO}_{2}$ in the atmosphere are longer, and the regional background contribution becomes important.

Thus, the $\mathrm{CO}$ and $\mathrm{SO}_{2}$ measurement results could be used for studying the spatial distributions of the air pollutants in the NCP region. The hotspots measured near large cities were mainly from local emissions.

\subsection{The influence of regional transport}

Local emissions and regional transport are the two main sources of pollutants in the NCP (Xu et al., 2011). As stated 
Table 4. Trip-average concentrations of $\mathrm{SO}_{2}, \mathrm{CO}$ and $\mathrm{BC}$ and wind directions on the days discussed in the paper.

\begin{tabular}{llrrrl}
\hline Route & Date & \multicolumn{2}{c}{ Concentrations (mean $\pm \mathrm{SD}, \mathrm{ppb})$} & \multirow{2}{*}{ Wind directions } \\
\cline { 3 - 5 } & & $\mathrm{SO}_{2}$ & $\mathrm{CO}$ & $\mathrm{BC}$ & \\
\hline Route 1 & 2 July & $4.5 \pm 2.3$ & $550 \pm 240$ & $5.0 \pm 2.6$ & northwest \\
Route 5 & 7 July & $7.0 \pm 3.0$ & $1090 \pm 320$ & $6.5 \pm 2.7$ & east \\
Route 1 & 24 June & $15 \pm 5.8$ & $1300 \pm 330$ & $8.0 \pm 1.4$ & south \\
Route 4 & 14 June & $26 \pm 7.9$ & $1200 \pm 230$ & $6.5 \pm 1.5$ & south \\
Route 5 & 15 June & $28 \pm 7.1$ & $1600 \pm 370$ & $7.0 \pm 1.9$ & south \\
Route 4 & 6 July & $14 \pm 7.6$ & $1100 \pm 450$ & $4.6 \pm 1.8$ & south \\
Route 2 & 12 June & $26 \pm 11$ & $950 \pm 440$ & $4.8 \pm 2.2$ & southwest \\
Route 2 & 18 June & $27 \pm 10$ & $1030 \pm 530$ & $6.8 \pm 2.3$ & northwest \\
Route 2 & 25 June & $27 \pm 16$ & $1020 \pm 680$ & $6.5 \pm 3.3$ & stable \\
Route 2 & 3 July & $23 \pm 15$ & $989 \pm 450$ & $5.7 \pm 2.6$ & southwest \\
\hline
\end{tabular}

above, local emissions in large cities had a major impact on the air quality in their adjacent areas. We found that all air pollutants measured near large cities were at a high level. According to the analysis in Sect. 3.2, they were mainly from local emissions of cities. In addition, according to the estimated emission inventories, these cities were major sources of air pollution that caused the concentrations of air pollution to be high around them. Regional transport also plays a major role. Our study demonstrated that the contribution of regional transport could vary both spatially and temporally, depending on a number of parameters, such as prevalent wind, terrain and vertical mixing. We also roughly divided the NCP into two parts according to these parameters, i.e. the northern border area and the central area, to discuss the influence of regional transport on air quality. All trip-average concentrations of $\mathrm{SO}_{2}, \mathrm{CO}$ and $\mathrm{BC}$ and wind directions on the days discussed in the paper are shown in Table 4.

\subsubsection{The border areas of NCP}

The northern border area of the NCP included major parts of routes 4 and 5 , and the western border areas of the NCP included a major part of route 1 . The area is surrounded by the Taihang Mountains to the west and the Yan Mountains to the north. The north wind prevailed in the winter and the south wind prevailed in the summer in this area.

During the measurements, the three routes experienced both north and south winds. Specifically, northwest winds and east winds brought air masses from outside the NCP from Northeast China and the Bohai Sea to the northern border area on 2 July (route 1) and 7 July (route 5), respectively (Fig. 7). On both trips, the concentrations of $\mathrm{SO}_{2}, \mathrm{CO}$ and $\mathrm{BC}$ were $4.5 \pm 2.3 \mathrm{ppb}, 550 \pm 240 \mathrm{ppb}$ and $5.0 \pm 2.6 \mathrm{~g} \mathrm{~m}^{-3}$, respectively, on 2 July and $7.0 \pm 3.0 \mathrm{ppb}, 1090 \pm 320 \mathrm{ppb}$ and $6.5 \pm 2.7 \mu \mathrm{g} \mathrm{m}^{-3}$, respectively, on 7 July (Fig. 2), which were the lowest values observed here in the border areas of the NCP. These observations were reasonable as areas including the Bohai Sea to the west, north and east of the NCP were regions of low emissions (Fig. 3) and the clean air brought by northeast and east winds could dilute the air pollutants in the border areas of the NCP.

It is worth noting that the $\mathrm{BC}$ concentration was not lowest on 2 July, which was the opposite of the observations for the gas pollutants, $\mathrm{SO}_{2}$ and $\mathrm{CO}$. Satellite images showed that there were many fire plots near route 1 on 2 July (Fig. S4). A featured single peak of aerosol number density at around $50 \mathrm{~nm}$ (Fig. S5) further confirmed that BC emissions from agricultural crop residue burning contributed significantly to the BC levels on 2 July (Zhang et al., 2011; Hays et al., 2005; Li et al., 2007).

On 24 June (route 1), 14 June (route 4) and 15 June (route 5), the air masses were transported inside the NCP from the southern NCP to the northern border areas by south winds (Fig. 7). Under these wind conditions, the concentrations of $\mathrm{SO}_{2}, \mathrm{CO}$ and $\mathrm{BC}$ were $15 \pm 5.8 \mathrm{ppb}$, $1300 \pm 330 \mathrm{ppb}$ and $8.0 \pm 1.4 \mu \mathrm{g} \mathrm{m}^{-3}$, respectively, on 24 June, $26 \pm 7.9 \mathrm{ppb}, 1200 \pm 230 \mathrm{ppb}$ and $6.5 \pm 1.5 \mu \mathrm{g} \mathrm{m}^{-3}$, respectively, on 14 June and $28 \pm 7.1 \mathrm{ppb}, 1600 \pm 370 \mathrm{ppb}$ and $7.0 \pm 1.9 \mu \mathrm{g} \mathrm{m}^{-3}$, respectively, on 15 June (Fig. 2), which were among the highest levels detected on these routes. According to the emissions inventories (Fig. 3), most emissions hotspots were located in the central and southern parts of the NCP. Pollutants could be easily accumulated in air masses of south and central NCP origin. In addition, the Yan Mountains to the north of the border area stopped the possible transport pathway of these air masses, which further enhanced the accumulation of long-lived air pollutants in the northern border area of the NCP.

Although route 4 on 6 July was under the influence of south winds, as the same route on 14 June (Fig. 7), the concentrations of $\mathrm{SO}_{2}$ and $\mathrm{BC}$ on 6 July were $14 \pm 7.6 \mathrm{ppb}$ and $4.6 \pm 1.8 \mu \mathrm{g} \mathrm{m}^{-3}$, respectively, which were much lower than the values of $26 \pm 7.9 \mathrm{ppb}$ and $6.5 \pm 1.5 \mu \mathrm{g} \mathrm{m}^{-3}$, respectively, on 14 June. Meanwhile, the CO levels on these 2 days were similar. One possible cause of the low concentrations of both $\mathrm{SO}_{2}$ and $\mathrm{BC}$ was the slightly higher boundary layer height on 6 July compared to 14 June. The precipitation that occurred 

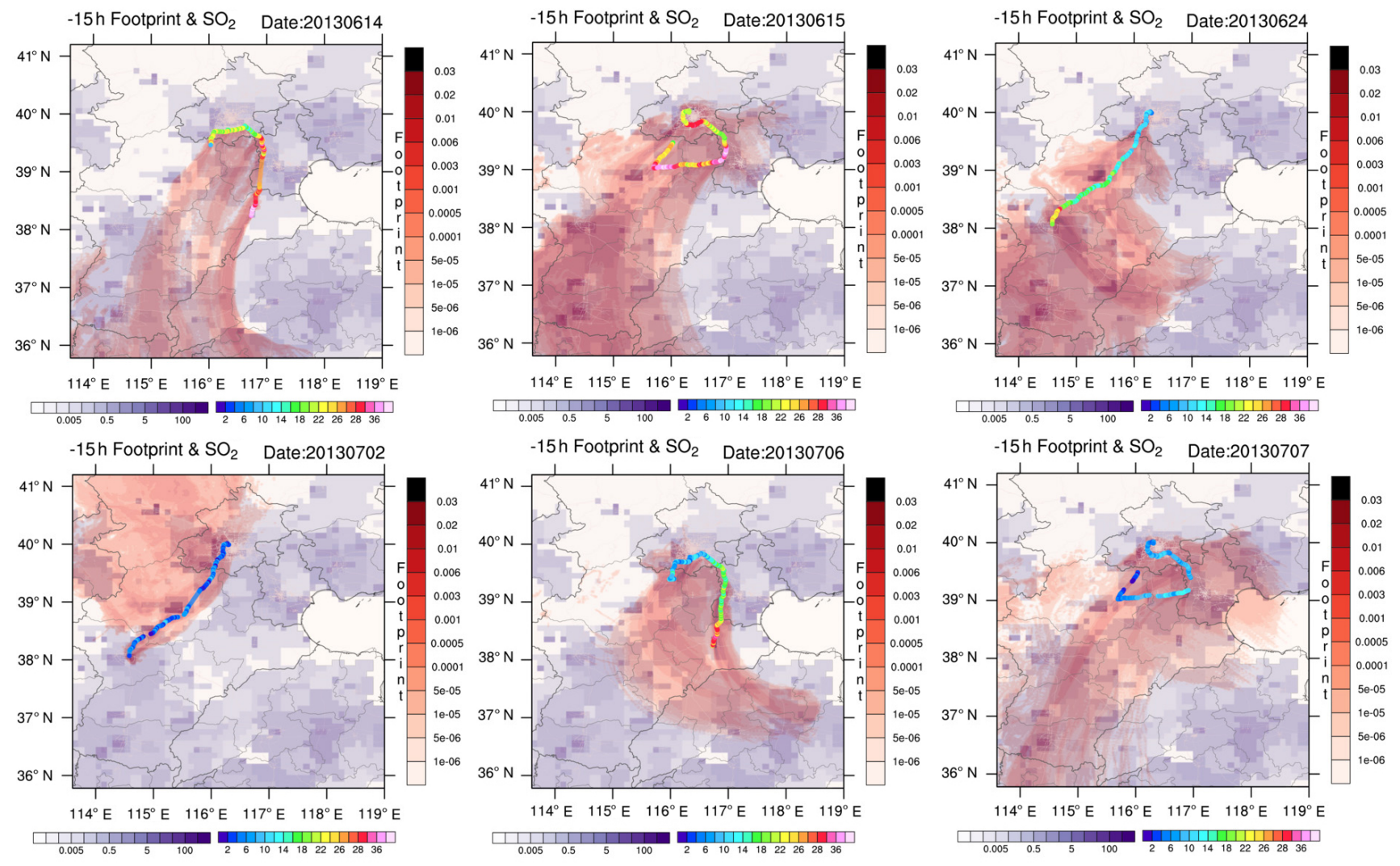

Figure 7. The back trajectories of observed air masses in the borders of the NCP on 14, 15 and 24 June and 2, 6 and 7 July.

on 6 July, but not on 14 June, appeared to be a more important contributing factor. The solubility of $\mathrm{CO}$ is less than that of $\mathrm{SO}_{2}$. Therefore, the wet deposition lifetime of $\mathrm{SO}_{2}$ would be much shorter, thus limiting the transport distance of $\mathrm{SO}_{2}$. Meanwhile, the wet deposition of $\mathrm{BC}$ particles would also prohibit its long-range transport. This may explain the similar $\mathrm{CO}$ levels and low $\mathrm{SO}_{2}$ and $\mathrm{BC}$ levels on 6 July at the same time.

In conclusion, for the northern border area, local emissions and regional transport from other NCP areas due to south winds were two main sources of long-lived pollutants; both north and east winds had significant dilution effects on the concentrations of gas pollutants. This is based on a general situation that the air quality in the north border of the North China Plain was clean because the emissions of air pollutants were low in that area (Fig. 3). The wind dependency scatter plots for $\mathrm{SO}_{2}$ were used to show the contribution of regional transport to air pollution in the northern border area of the NCP (Fig. 8). The results indicated that the high concentration was connected to the south wind at a wind speed from 4 to $10 \mathrm{~m} \mathrm{~s}^{-1}$. Similar results for $\mathrm{SO}_{2}$ and $\mathrm{CO}$ were reported for several sites in the northern NCP (Xu et al., 2011; Lin et al., 2011, 2009). As the south wind usually prevailed in the summer and north wind prevailed in the winter, the regional transport of long-lived pollutants within the NCP from the central and southern parts to the northern parts should be prevalent in the summer; the dilution of air pollutants mainly by north winds and occasionally east winds should be prevalent for the northern parts of the NCP in the winter.

\subsubsection{The central NCP}

The central NCP consisted of routes 2 and 3, where numerous heavily polluted cities are located. The area was surrounded by the Taihang Mountains to the west or emissions hotspots in other directions. While the north wind prevailed in the winter, as for the northern border areas, low pressure prevailed in the summer with south and northeast winds in this area.

During the observation period, the measurements along the two routes experienced different wind fields. Route 2 experienced southwest winds on 12 June and 3 July, northeast winds on 18 June and a low-pressure system with south and northeast winds on 25 June (Fig. S6). Unlike the northern border area of the NCP where strong north winds had a dilution effect, the concentrations of gas pollutants were mostly high regardless of the wind direction on route 2 in the central NCP, e.g. on 18 June and 3 July (Fig. S6). Generally, our observations were reasonable according to the unique terrain and emissions map in the central NCP. Due to the heavy 

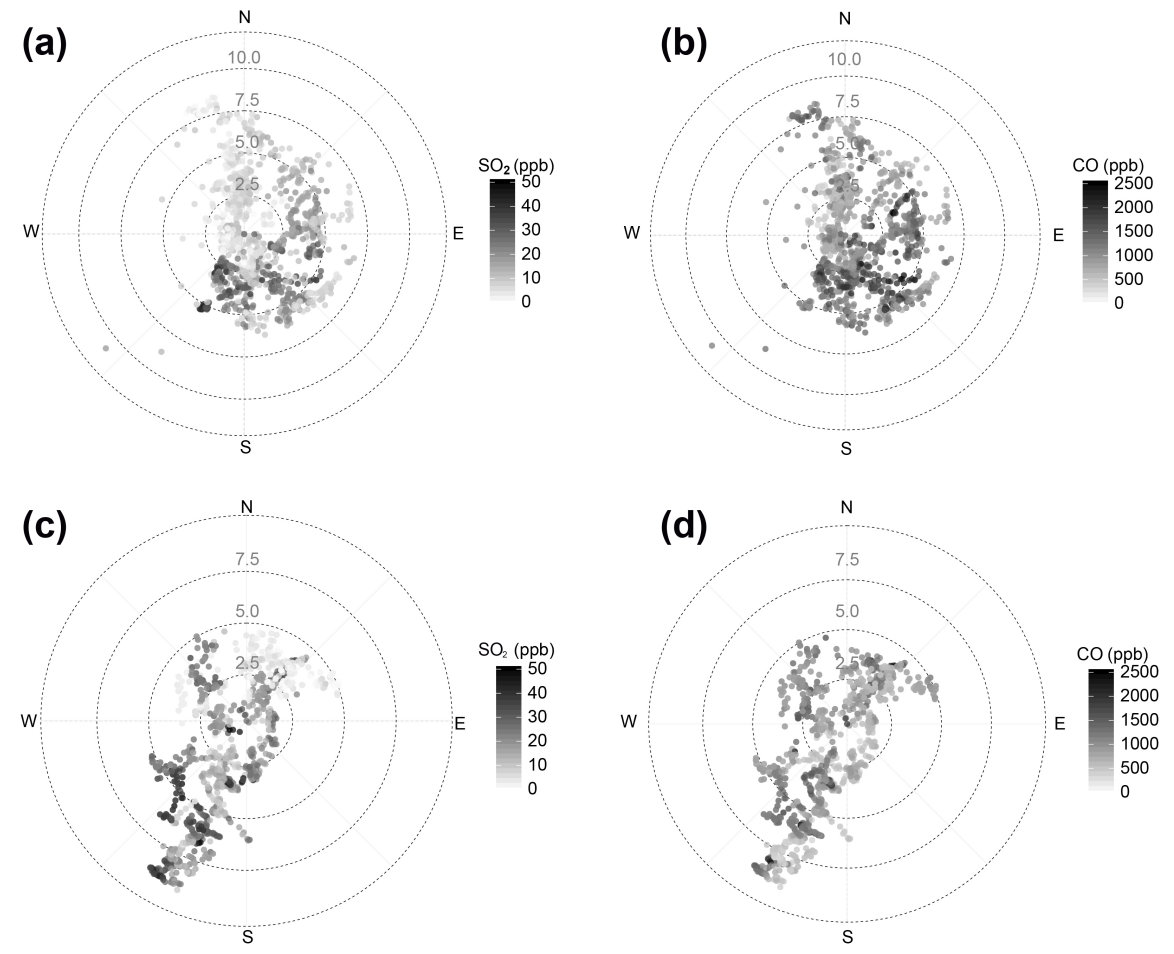

Figure 8. Wind dependency scatter plots of concentrations of $\mathrm{SO}_{2}$ and $\mathrm{CO}$ in border and central areas in $\mathrm{NCP}$. (a) $\mathrm{SO}_{2}$ in border area; (b) $\mathrm{CO}$ in border area; (c) $\mathrm{SO}_{2}$ in central area; (d) $\mathrm{CO}$ in central area.

emissions level in the central NCP and surrounding areas, pollutants readily accumulated to high levels on their way to the central NCP in air masses from all directions, such as the clean air masses from the Bohai Sea, western China and Northeast China, and polluted air masses from Southeast China.

The situation was slightly different in areas along route 3 , particularly for those off the coast of the Bohai Sea. Route 3 experienced east winds on 14 July (Fig. S6), and the concentrations of pollutants were low (Fig. 2). This was not only because of the wet deposition from the rain on that day, but also because of the transport of clean air from the Bohai Sea. A featured peak of aerosol number density at around $20 \mathrm{~nm}$ (Fig. S5) further confirmed the incoming air from the Bohai Sea (Haaf and Jaenicke, 1980; Hoppel et al., 1986).

Vertical mixing can also affect the concentrations of pollutants. For example, while the wind fields were similar on route 3 on 13 June and 4 July (Fig. 9), the concentration of pollutants on 13 June was lower than that on 4 July (Fig. 2). This was because the boundary layer was much higher on 13 June $(976 \mathrm{~m})$ than on 4 July $(626 \mathrm{~m})$, and the strong vertical convection diluted the air pollutants.

Specifically, the relative contributions of emissions and regional transport to the local air pollution levels were slightly different on different routes. At the junction of routes 1 and 2 around Shijiazhuang area, the concentrations of air pollutants were always high, except in the last experiment when wet precipitation occurred. The local emissions contributed significantly to the air pollution levels in this area. The city of Shijiazhuang is known as an emissions hotspot with heavy coal consumption. Previous model results showed that Shijiazhuang is an important emissions hotspot of $\mathrm{SO}_{2}$, even in the whole NCP area (He et al., 2012). Meanwhile, the Taihang Mountains to the west of the city prevented the diffusion of air pollutants. On the other hand, transport convergence in front of the Taihang Mountains and Yan Mountains was proposed in a previous study (Su et al., 2004), as a result of a low-pressure system along the Taihang Mountains and Yan Mountains. Although the position of the northern part of the transport convergence moved around, it always passed by the Shijiazhuang area. As shown in Fig. 3, high levels of pollutants, particularly relatively long-lived species such as $\mathrm{SO}_{2}$ and $\mathrm{CO}$, were consistently observed at the western end of route 2 near the Shijiazhuang area. Broad peaks of $\mathrm{SO}_{2}$ and $\mathrm{CO}$ concentrations, indicators of regional transport plumes, were present near Shijiazhuang area (Fig. S7).

Similar to the situation in the Shijiazhuang area, transport convergence would occasionally pass through other cities along routes 2 and 3. In a typical case on 13 June (Fig. 9), air masses were transported far from the southwest of the NCP along the transport convergence through Shijiazhuang and reached the area on route 3 , with air pollutants accumulating during transport and showing high concentrations. 

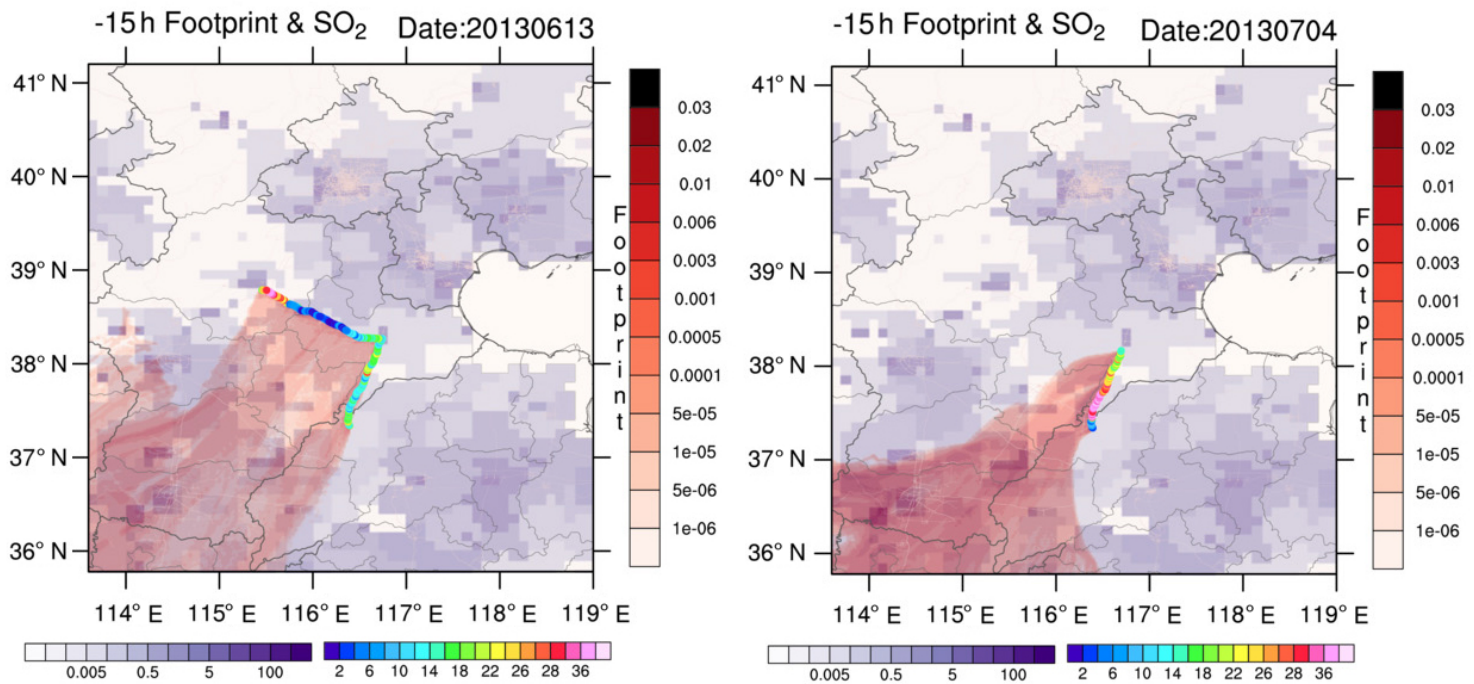

Figure 9. The back trajectories of observed air masses in the central NCP on 13 June and 4 July.

Overall, in most areas in the central NCP, regional transport would play essential roles in determining the local air pollution levels, although the underlying mechanisms were different for the transport convergence area, central NCP area and coastal area. The wind dependence scatter plots for $\mathrm{SO}_{2}$ and $\mathrm{CO}$ were used as examples to show the contribution of regional transport to air pollution in the central NCP (Fig. 8). The results indicated that the prevailing winds were southwest and northeast in the central NCP during our observation period. The concentrations of $\mathrm{CO}$ were independent of wind direction and wind speed. In addition, the high concentrations of $\mathrm{SO}_{2}$ were related to southeast winds with high speed, which was about $5-10 \mathrm{~m} \mathrm{~s}^{-1}$. This may have been because of transport convergence. Due to the strong interaction of different areas in the central NCP, emissions control policies must consider the whole emissions budget to achieve the air quality aims.

We discussed five impactors: local emission, precipitation, location, wind direction and boundary layer height. The influence of local emission was reflected in the spatial distribution of concentrations (Fig. 3). Hotspots were found near cities. However, for route-average results (Fig. 2), local emission plays a minor role in the distribution of concentrations because the routes were mainly in suburbs. The large reduction in $\mathrm{SO}_{2}$ and $\mathrm{NO}_{x}$ concentration measured on 12 July along all routes was caused by precipitation. The persistent high concentrations of pollutants on route 2 were associated with the location of it, which was surrounded by high emission areas. Besides route 2, the different concentrations on one route in different measurements were mainly from different wind directions. In addition, we also found one case in which the concentrations changed a lot between 13 June and 4 July on route 3 under similar wind directions. Based on the model results, boundary layer height might explain the change.

\section{Conclusion}

A mobile laboratory was employed to obtain snapshots of the spatial distributions of air pollutants in the NCP. The concentrations observed were at the highest levels in the world and were distributed unevenly in the NCP. Most high concentrations of air pollutants, i.e. 95 percentile concentrations, were found near emissions hotspots, which suggested the influence of local emissions. However, regional transport of air pollutants was also considered significant in determining the air quality in the NCP. Back trajectory analysis, satellite data and tracer pollutants were combined to recognise various cases of regional transport in both the northern border and the central NCP. Where the border areas would occasionally be diluted by winds from outside the NCP, the central NCP was affected by regional transport of air pollutants with a few exceptions, such as when precipitation occurred. To achieve the aims of air quality locally, emissions control policies must consider the whole emissions budget in the NCP.

\section{Data availability}

The data of mobile and stationary measurements are available upon request. We are also working on installing a website this year. We will provide data of GPSs, vehicle speed, meteorology and concentrations of air pollutants.

The Supplement related to this article is available online at doi:10.5194/acp-16-12551-2016-supplement. 
Author contributions. T. Zhu, Y. Zhu, Y. Han and W. Chen designed the experiments. T. Zhu secured the research grants. Y. Zhu, Y. Han and W. Chen carried out the experiments. J. Zhang developed the model code and performed the simulations. J. Wang managed the data in the program. J. Liu provided the emission maps. L. Zeng, Y. Wu, X. Wang, W. Wang and J. Chen provided the data of stationary measurements. Y. Zhu analysed the data with contributions from all co-authors. Y. Zhu prepared the manuscript with help from T. Zhu, C. Ye and Y. Li.

Acknowledgements. This study was supported by the National Natural Science Foundation Committee of China (21190051, 41121004, 41421064), the European Seventh Framework Programme Project PURGE (265325), the Collaborative Innovation Center for Regional Environmental Quality and the National Key Research and Development Program of China (2016YFC0209000).

Edited by: D. Heard

Reviewed by: two anonymous referees

\section{References}

An, X., Zhu, T., Wang, Z., Li, C., and Wang, Y.: A modeling analysis of a heavy air pollution episode occurred in Beijing, Atmos. Chem. Phys., 7, 3103-3114, doi:10.5194/acp-7-3103-2007, 2007.

Ashbaugh, L. L., Malm, W. C., and Sadeh, W. Z.: A residence time probability analysis of sulfur concentrations at Grand Canyon National Park, Atmos. Environ., 19, 1263-1270, 1985.

Bechle, M. J., Millet, D. B., and Marshall, J. D.: Effects of income and urban form on urban $\mathrm{NO}_{2}$ : Global evidence from satellites, Environ. Sci. Technol., 45, 4914-4919, doi:10.1021/es103866b, 2011

Brioude, J., Arnold, D., Stohl, A., Cassiani, M., Morton, D., Seibert, P., Angevine, W., Evan, S., Dingwell, A., Fast, J. D., Easter, R. C., Pisso, I., Burkhart, J., and Wotawa, G.: The Lagrangian particle dispersion model FLEXPART-WRF version 3.1, Geosci. Model Dev., 6, 1889-1904, doi:10.5194/gmd6-1889-2013, 2013.

Bucsela, E. J., Krotkov, N. A., Celarier, E. A., Lamsal, L. N., Swartz, W. H., Bhartia, P. K., Boersma, K. F., Veefkind, J. P., Gleason, J. F., and Pickering, K. E.: A new stratospheric and tropospheric $\mathrm{NO}_{2}$ retrieval algorithm for nadir-viewing satellite instruments: applications to OMI, Atmos. Meas. Tech., 6, 26072626, doi:10.5194/amt-6-2607-2013, 2013.

Bukowiecki, N., Dommen, J., Prévôt, A. S. H., Richter, R., Weingartner, E., and Baltensperger, U.: A mobile pollutant measurement laboratory-measuring gas phase and aerosol ambient concentrations with high spatial and temporal resolution, Atmos. Environ., 36, 5569-5579, 2002.

Cai, H. and Xie, S.: Estimation of vehicular emission inventories in China from 1980 to 2005, Atmos. Environ., 41, 8963-8979, 2007

Cai, H. and Xie, S.: Determination of emission factors from motor vehicles under different emission standard in China, Acta Scientiarum Naturalium Universitatis Pekinensis, 46, 319-326, 2010.
Chinese Automotive Technology \& Research Centre: China Automotive Industry Yearbook, Tianjin, China, 2015.

de Foy, B., Zavala, M., Bei, N., and Molina, L. T.: Evaluation of WRF mesoscale simulations and particle trajectory analysis for the MILAGRO field campaign, Atmos. Chem. Phys., 9, 44194438, doi:10.5194/acp-9-4419-2009, 2009.

Ding, A., Wang, T., Xue, L., Gao, J., Stohl, A., Lei, H. C., Jin, D. Z., Ren, Y., Wang, X. Z., Wei, X. L., Qi, Y. B., Liu, J., and Zhang, X. Q.: Transport of north China air pollution by midlatitude cyclones: Case study of aircraft measurements in summer 2007, J. Geophys. Res., 114, D11399, doi:10.1029/2009JD012339, 2009.

Ding, K., Liu, J., Ding, A., Liu, Q., Zhao, T. L., Shi, J., Han, Y., Wang, H., and Jiang, F.: Uplifting of carbon monoxide from biomass burning and anthropogenic sources to the free troposphere in East Asia, Atmos. Chem. Phys., 15, 2843-2866, doi:10.5194/acp-15-2843-2015, 2015.

Donkelaar, V. A., Martin, R. V., Brauer, M., Kahn, R., Levy, R., Verduzco, C., and Villeneuve, P. J.: Global estimates of ambient Fine particulate matter concentrations from satellite-based aerosol optical depth: development and application, Environ. Health Persp., 118, 847-855, doi:10.1289/ehp.0901623, 2010.

Fast, J. D. and Easter, R. C.: A Lagrangian particle dispersion model compatible with WRF, in: 7th WRF User's Workshop, NCAR, P6-02, 19-22 June 2006, Boulder, Colorado, USA, 2006.

Finlayson-Pitts, B. J. and Pitts, J. N.: Chemistry of the upper and lower atmosphere, Academic press, San Diego, California, USA, 2010.

Haaf, W. and Jaenicke, R.: Results of improved size distribution measurements in the Aitken range of atmospheric aerosols, J. Aerosol Sci., 11, 321-330, doi:10.1016/0021-8502(80)90106-8, 1980.

Hagemann, R., Corsmeier, U., Kottmeier, C., Rinke, R., Wieser, A., and Vogel, B.: Spatial variability of particle number concentrations and $\mathrm{NO}_{x}$ in the Karlsruhe (Germany) area obtained with the mobile laboratory "AERO-TRAM", Atmos. Environ., 94, 341352, doi:10.1016/j.atmosenv.2014.05.051, 2014.

Hays, M. D., Fine, P. M., Geron, C. D., Kleeman, M. J., and Gullett, B. K.: Open burning of agriculture biomass: physical and chemical properties of particle-phase emissions, Atmos. Environ., 39, 6747-6764, 2005.

He, H., Li, C., Loughner, C. P., Li, Z., Krotkov, N. A., Yang, K., Wang, L., Zheng, Y., Bao, X., Zhao, G., and Dickerson, R. R.: $\mathrm{SO}_{2}$ over central China: Measurements, numerical simulations and the tropospheric sulfur budget, J. Geophys. Res., 117, D00K37, doi:10.1029/2011JD016473, 2012.

Hoppel, W. A., Frick, G. M., and Larson, R. E.: Effect of nonprecipitating clouds on the aerosol size distribution in the marine boundary layer, Geophys. Res. Lett., 13, 125-128, doi:10.1029/GL013i002p00125, 1986.

Hu J., Wang Y., Ying Q., and Zhang H.: Spatial and temporal variability of $\mathrm{PM}_{2.5}$ and $\mathrm{PM}_{10}$ over the North China Plain and the Yangtze River Delta, China, Atmos. Environ., 95, 598-609, 2014.

Huang, K., Zhuang, G., Lin, Y., Li, J., Sun, Y., Zhang, W., and $\mathrm{Fu}, \mathrm{S}$.: Relation between optical and chemical properties of dust aerosol over Beijing, China, J. Geophys. Res., 115, D00K16, doi:10.1029/2009JD013212, 2010.

Johansson, M., Galle, B., Yu, T., Tang, L., Chen, D., Li, H., Li, J., and Zhang, Y.: Quantification of total emission of air pollu- 
tants from beijing using mobile mini-doas, Atmos. Environ., 42, 6926-6933, doi:10.1016/j.atmosenv.2008.05.025, 2008.

Kolb, C., Herndon, S., Mcmanus, J. B., Shorter, J., Zahniser, M., Nelson, D., and Jayne, J., Canagaratna, M. R., and Worsnop, D. R.: Mobile laboratory with rapid response instruments for realtime measurements of urban and regional trace gas and particulate distributions and emission source characteristics, Environ. Sci. Technol. 38, 5694-5703, doi:10.1021/es030718p, 2004.

Lei, Y., Zhang, Q., He, K. B., and Streets, D. G.: Primary anthropogenic aerosol emission trends for China, 1990-2005, Atmos. Chem. Phys., 11, 931-954, doi:10.5194/acp-11-931-2011, 2011.

Li, A., Xie, P., Liu, W., Liu, J., and Dou, K.: Studies on the determination of the flux of gaseous pollutant from an area by passive differential optical absorption spectroscopy, Spectrosc. Spect. Anal., 29, 28-32, doi:10.3964/j.issn.1000-0593(2009)010028-05, 2009 (in Chinese).

Li, A., Zhang, J., Xie, P., Hu, Z., Xu, J., Mou, F., Wu, F., Liu, J., and Liu, W.: Variation of temporal and spatial patterns of $\mathrm{NO}_{2}$ in Beijing using OMI and mobile DOAS, Science China Chemistry, 58, 1367-1376, 2015.

Li, X., Wang, S., Duan, L., Hao, J., Li, C., Chen, Y., and Yang, L.: Particulate and trace gas emissions from open burning of wheat straw and corn stoves in China, Environ. Sci. Technol., 41, 60526058, doi:10.1021/es0705137, 2007.

Lin, W., Xu, X., Ge, B., and Zhang, X.: Characteristics of gaseous pollutants at Gucheng, a rural site southwest of Beijing, J. Geophys. Res., 114, D00G14, doi:10.1029/2008JD010339, 2009.

Lin, W., Xu, X., Ge, B., and Liu, X.: Gaseous pollutants in Beijing urban area during the heating period 2007-2008: variability, sources, meteorological, and chemical impacts, Atmos. Chem. Phys., 11, 8157-8170, doi:10.5194/acp-11-8157-2011, 2011.

Liu, X. G., Li, J., Qu, Y., Han, T., Hou, L., Gu, J., Chen, C., Yang, Y., Liu, X., Yang, T., Zhang, Y., Tian, H., and Hu, M.: Formation and evolution mechanism of regional haze: a case study in the megacity Beijing, China, Atmos. Chem. Phys., 13, 4501-4514, doi:10.5194/acp-13-4501-2013, 2013.

Meng, Z. Y., Xu, X. B., Yan, P., Ding, G. A., Tang, J., Lin, W. L., Xu, X. D., and Wang, S. F.: Characteristics of trace gaseous pollutants at a regional background station in Northern China, Atmos. Chem. Phys., 9, 927-936, doi:10.5194/acp-9-927-2009, 2009.

Padró-Martínez, L. T., Patton, A. P., Trull, J. B., Zamore, W., Brugge, D., and Durant, J. L.: Mobile monitoring of particle number concentration and other traffic-related air pollutants in a near-highway neighborhood over the course of a year, Atmos. Environ., 61, 253-264, 2012.

Shen, X., Yao, Z., Zhang, Q., Wagner, D. V., Huo, H., Zhang, Y., Zheng, B., and He, K.: Development of database of real-world diesel vehicle emission factors for China, J. Environ. Sci., 31, 209-220, doi:10.1016/j.jes.2014.10.021, 2015.

Shen, X. J., Sun, J. Y., Zhang, Y. M., Wehner, B., Nowak, A., Tuch, T., Zhang, X. C., Wang, T. T., Zhou, H. G., Zhang, X. L., Dong, F., Birmili, W., and Wiedensohler, A.: First long-term study of particle number size distributions and new particle formation events of regional aerosol in the North China Plain, Atmos. Chem. Phys., 11, 1565-1580, doi:10.5194/acp-11-15652011, 2011.

Shi, C., Fernand, H. J. S., Wang, Z., An, X., and Wu, Q.: Tropospheric $\mathrm{NO}_{2}$ columns over East Central China: Comparisons be- tween SCIAMACHY measurements and nested CMAQ simulations, Atmos. Environ., 42, 7165-7173, 2008.

Stohl, A.: Computation, accuracy and applications of trajectories A review and bibliography, Atmos. Environ., 32, 947-966, 1998.

Stohl, A., Forster, C., Frank, A., Seibert, P., and Wotawa, G.: Technical note: The Lagrangian particle dispersion model FLEXPART version 6.2, Atmos. Chem. Phys., 5, 2461-2474, doi:10.5194/acp-5-2461-2005, 2005.

Streets, D. G., Canty, T., Carmichael, G. R., Foy, B. D., Dickerson, R. R., Duncan, B. N., Edwards, D. P., Haynes, J. A., Henze, D. K., Houyoux, M. R., Jacob, D. J., Krotkov, N. A., Lamsal, L. N., Liu, Y., Lu, Z. F., Martin, R. V., Pfister, G. G., Pinderm, R. W., Salawitch, R. J., and Wecht, K. J.: Emissions estimation from satellite retrievals: A review of current capability, Atmos. Environ., 77, 1011-1042, 2013.

Su, F., Ren Z., Gao, Q., and Zhang Z.: Convergence System of Air Contamination in Boundary Layer above Beijing and North China: Transport Convergence in Boundary Layer, Res. Environ. Sci., 17, 21-25, doi:10.13198/j.res.2004.01.23.sufq.004, 2004.

Wang, M., Zhu, T., Zheng, J., Zhang, R. Y., Zhang, S. Q., Xie, X. X., Han, Y. Q., and Li, Y.: Use of a mobile laboratory to evaluate changes in on-road air pollutants during the Beijing 2008 Summer Olympics, Atmos. Chem. Phys., 9, 8247-8263, doi:10.5194/acp-9-8247-2009, 2009.

Wang, M., Zhu, T., Zhang, J. P., Zhang, Q. H., Lin, W. W., Li, Y., and Wang, Z. F.: Using a mobile laboratory to characterize the distribution and transport of sulfur dioxide in and around Beijing, Atmos. Chem. Phys., 11, 11631-11645, doi:10.5194/acp11-11631-2011, 2011.

Wang, S., Li, G., Gong, Z., Du, L., Zhou, Q., Meng, X., Xie, S., and Zhou, L.: Spatial distribution, seasonal variation and regionalization of $\mathrm{PM}_{2.5}$ concentrations in China, Science China Chemistry, 58, 1435-1443, 2015.

Wang, Y., Yao, L., Wang, L., Liu, Z., Ji, D., Tang, G., Zhang, J., Sun, Y., Hu, B., and Xin, J.: Mechanism for the formation of the January 2013 heavy haze pollution episode over central and eastern China, Sci. China Ser. D, 57, 14-25, doi:10.1007/s11430013-4773-4, 2014.

Wang, Z. B., Hu, M., Sun, J. Y., Wu, Z. J., Yue, D. L., Shen, X. J., Zhang, Y. M., Pei, X. Y., Cheng, Y. F., and Wiedensohler, A.: Characteristics of regional new particle formation in urban and regional background environments in the North China Plain, Atmos. Chem. Phys., 13, 12495-12506, doi:10.5194/acp13-12495-2013, 2013.

Wei, P., Cheng, S., Li, J., and Su, F.: Impact of boundary-layer anticyclonic weather system on regional air quality, Atmos. Environ., 45, 2453-2463, 2011.

Wen, L., Chen, J., Yang, L., Wang, X., Xu, C., Sui, X., Yao, L, Zhu, Y., Zhang, J., Zhu, T., and Wang, W.: Enhanced formation of fine particulate nitrate at a rural site on the North China Plain in summer: The important roles of ammonia and ozone, Atmos. Environ., 101, 294-302, 2015.

Westerdahl, D., Fruin, S., Sax, T., Fine, P., and Sioutas, C.: Mobile platform measurements of ultrafine particles and associated pollutant concentrations on freeways and residential streets in Los Angeles, Atmos. Environ., 39, 3597-3610, 2005.

Xu, W. Y., Zhao, C. S., Ran, L., Deng, Z. Z., Liu, P. F., Ma, N., Lin, W. L., Xu, X. B., Yan, P., He, X., Yu, J., Liang, W. D., and Chen, L. L.: Characteristics of pollutants and their correlation to 
meteorological conditions at a suburban site in the North China Plain, Atmos. Chem. Phys., 11, 4353-4369, doi:10.5194/acp-114353-2011, 2011.

Xu, W. Y., Zhao, C. S., Ran, L., Lin, W. L., Yan, P., and Xu, X. B.: $\mathrm{SO}_{2}$ noontime-peak phenomenon in the North China Plain, Atmos. Chem. Phys., 14, 7757-7768, doi:10.5194/acp-14-77572014, 2014.

Ying, Q., Wu, L., and Zhang, H.: Local and inter-regional contributions to $\mathrm{PM}_{2.5}$ nitrate and sulfate in China, Atmos. Environ., 94, 582-592, 2014.

Yu, F., Luo, G., Bates, T. S., Anderson, B., Clarke, A., Kapustin, V., Yantosca, R. M., Wang, Y., and Wu, S.: Spatial distributions of particle number concentrations in the global troposphere: Simulations, observations, and implications for nucleation mechanisms, J. Geophys. Res., 115, D17205, doi:10.1029/2009JD013473, 2010.

Zhang, J. P., Zhu, T., Zhang, Q. H., Li, C. C., Shu, H. L., Ying, Y., Dai, Z. P., Wang, X., Liu, X. Y., Liang, A. M., Shen, H. X., and Yi, B. Q.: The impact of circulation patterns on regional transport pathways and air quality over Beijing and its surroundings, Atmos. Chem. Phys., 12, 5031-5053, doi:10.5194/acp-12-50312012, 2012.
Zhang, Q., Ma, X., Tie, X., Huang, M., and Zhao, C.: Vertical distributions of aerosols under different weather conditions: Analysis of in-situ aircraft measurements in Beijing, China, Atmos. Environ., 43, 5526-5535, 2009.

Zhang, Q., Quan, J., Tie, X., Huang, M., and Ma, X.: Impact of aerosol particles on cloud formation: Aircraft measurements in China, Atmos. Environ., 45, 665-672, 2011.

Zhang, W., Zhu, T., Yang, W., Bai, Z., Sun, Y. L., Xu, Y., Yin, B., and Zhao, X.: Airborne measurements of gas and particle pollutants during CAREBeijing-2008, Atmos. Chem. Phys., 14, 301316, doi:10.5194/acp-14-301-2014, 2014.

Zhang, Y., Hua, M., Zhong, L., Wiedensohler, A., Liu, S., Andreae, M. O., Wang, W., and Fan, S.: Regional Integrated Experiments on Air Quality over Pearl River Delta 2004 (PRIDE-PRD2004): Overview, Atmos. Environ., 42, 6157-6173, 2008.

Zhao, B., Wang, S., Wang, J., Fu, J., Liu, T., Xu, J., Fu, X., and Hao, J.: Impact of national $\mathrm{NO}_{x}$ and $\mathrm{SO}_{2}$ control policies on particulate matter pollution in China, Atmos. Environ., 77, 453463, 2013. 